\title{
VASOPRESSIN AUGMENTS DEPOLARIZATION-INDUCED RELEASE AND SYNTHESIS OF SEROTONIN IN HIPPOCAMPAL SLICES ${ }^{1}$
}

\author{
SIDNEY AUERBACH ${ }^{2}$ AND PETER LIPTON
}

Department of Physiology, University of Wisconsin, Madison, Wisconsin 53706

Received June 2, 1981; Revised November 13, 1981; Accepted November 24, 1981

\begin{abstract}
Vasopressin may be a neurotransmitter and in vivo experiments suggest that it acts on monoamine metabolism. The rat hippocampal slice contains serotonergic nerve terminals but not cell bodies; we studied the effect of vasopressin on the synthesis and release of serotonin from these nerve terminals during depolarization. Incubation of slices in a buffer containing $60 \mathrm{~mm} \mathrm{~K} \mathrm{~K}^{+}$(high $\mathrm{K}$ buffer) for 10 min stimulated the release of serotonin into bathing medium and resulted in a $\mathrm{Ca}^{2+}$-dependent depletion of tissue serotonin from about 4.2 to about $2.8 \mathrm{ng} / \mathrm{mg}$ of protein. Vasopressin $\left(10^{-7} \mathrm{M}\right)$ inhibited this depletion by about $70 \%$ so that serotonin levels fell only to $3.8 \mathrm{ng} / \mathrm{mg}$ of protein. The peptide also augmented the high $\mathrm{K}^{+}$-induced release of serotonin into the bathing medium by about $60 \%$. The synthesis of serotonin was measured by determining its accumulation during a period when its catabolism was inhibited by pargyline. Vasopressin augmented the synthesis of serotonin in slices incubated in high $\mathrm{K}$ buffer by about $60 \%$. There are serotonergic nerve endings in both the dentate gyrus and CA1 regions of the hippocampus. The effect of vasopressin on tissue serotonin was confined to the dentate gyrus region. The data show that vasopressin acts on a specific group of hippocampal nerve endings to increase serotonin synthesis. The resulting increase in tissue serotonin may be the factor leading to the observed increase in serotonin release.
\end{abstract}

Vasopressin-containing nerve fibers have been observed in several regions of the mammalian central nervous system, including the hippocampus (Buijs, 1978), and nerve endings containing the peptide synapse near proximal dendrites in the limbic system (Sofroniew, 1980). Vasopressin, acting in the central nervous system, facilitates memory formation in rats (Bohus et al., 1978) and humans (Weingartner et al., 1981) and in vivo studies have shown that the peptide activates norepinephrine turnover in several limbic structures (Versteeg et al., 1978); these two effects may be related (Kovács et al., 1979). The effects of vasopressin on behavior also have been correlated with alterations of serotonin metabolism (Ramaekers et al., 1977), but there is no firm evidence as to the mechanism and site of its action. In an effort to define a site and determine the mechanism of vasopressin action, we have studied its effect on serotonin metabolism in the hippocampal slice. The slice contains two dense regions of serotonergic terminals and axon endings

\footnotetext{
${ }^{1}$ This work was supported by National Institutes of Health Grant NS 15878. We are grateful to Sharon Meinholz for secretarial assistance and Patricia Stellmacher for assistance in carrying out the experiments.

${ }^{2}$ To whom correspondence should be addressed at Department of Physiology, University of Wisconsin, 470 N. Charter Street, Madison, WI 53706 .
}

(Moore and Halaris, 1975). We find that vasopressin markedly activates the release and synthesis of serotonin during depolarization of these nerve terminals.

\section{Materials and Methods}

Male Holtzman rats (180 to $300 \mathrm{gm}$ ) were housed on a 12-hr light-dark cycle and fed rat chow and water ad libitum. They were decapitated, the brains were removed rapidly, and the hippocampi were excised and put into ice cold buffer (see below for buffer composition). Transverse slices ( $400 \mu \mathrm{m}$ thick) were cut from the hippocampus (Skrede and Westgaard, 1971) and put into a modified Krebs bicarbonate buffer gassed with $95 \% \mathrm{O}_{2}, 5 \%$ $\mathrm{CO}_{2}$. The temperature was $35^{\circ} \mathrm{C} ; \mathrm{pH}=7.4$. The buffer composition was: $\mathrm{NaCl}, 126 \mathrm{~mm}$; KCl, $1.8 \mathrm{~mm} ; \mathrm{KH}_{2} \mathrm{PO}_{4}$, $1.24 \mathrm{~mm} ; \mathrm{MgSO}_{4}, 1.3 \mathrm{~mm} ; \mathrm{NaHCO}_{3}, 26 \mathrm{~mm} ; \mathrm{CaCl}_{2}, 2.4$ $\mathrm{mM}$; dextrose, $10 \mathrm{~mm}$. Slices were bubbled rapidly enough to keep them moving in the incubating beakers. For all experiments, several control and experimental beakers were treated simultaneously. Hippocampal slices from two or three rats were pooled and divided into eight beakers. Typically, four of these beakers contained control tissue samples and four held experimental samples. Each beaker contained about $50 \mathrm{mg}$ of tissue in $20 \mathrm{ml}$ of buffer. In all cases, tissue was incubated in the buffer for $60 \mathrm{~min}$, then transferred to fresh buffer, and then sub- 
jected to experimental manipulation during a period not exceeding $30 \mathrm{~min}$. These times were chosen on the basis of preliminary experiments in which we found that tissue serotonin increased during $60 \mathrm{~min}$ incubation and then remained constant for the next $30 \mathrm{~min}$. This is shown in Table I.

Measurement of tissue serotonin. After the experiment, the buffer was drained from the slices. The slices were removed into liquid nitrogen within $5 \mathrm{sec}$ and then rapidly weighed while still frozen. Tissue was homogenized in $10 \mathrm{vol}$ of $0.1 \mathrm{~N} \mathrm{HCl}$; the suspension was centrifuged at $20,000 \times g$ for $20 \mathrm{~min}$ and the supernatant was assayed for serotonin by a standard radioenzymatic assay (Saavedra, 1977). The precipitate was assayed for protein as described by Lowry et al. (1951). Results were expressed as nanograms of serotonin per $\mathrm{mg}$ of protein.

\section{TABLE I}

Tissue levels of serotonin during incubation in normal Krebs buffer

Slices were incubated for the times shown in normal Krebs buffer and then analyzed for tissue serotonin. Each value is the mean of 5 experimental samples \pm SEM.

\begin{tabular}{cc}
\hline Incubation Time & Serotonin Levels \\
\hline $\min$ & $n g / m g$ protein \\
30 & $2.97 \pm 0.18$ \\
45 & $3.08 \pm 0.34$ \\
60 & $3.82 \pm 0.43$ \\
90 & $3.82 \pm 0.53$ \\
\hline
\end{tabular}

Measurement of serotonin release. At the beginning of the period during which release was to be measured, slices were transferred to beakers containing $5 \mathrm{ml}$ of fresh buffer and $1 \times 10^{-5} \mathrm{M}$ imipramine $\left(1 \times 10^{-5} \mathrm{M}\right.$ imipramine has been shown to inhibit serotonin re-uptake completely (Shaskan and Snyder, 1970)). The buffer was collected after a 10-min release period and was passed over a Sephadex G-10 column. Serotonin was eluted with $0.5 \mathrm{~N}$ formic acid (Boireau et al., 1976); eluates were lyophilized, redissolved in $0.1 \mathrm{~N} \mathrm{HCl}$, and assayed for serotonin radioenzymatically. External standards were run in triplicate in parallel with samples. All release values were corrected hy the percentage of recovery.

Measurement of serotonin synthesis. The synthesis of serotonin was calculated by measuring the accumulation of serotonin following the addition of $1 \times 10^{-4} \mathrm{M}$ pargyline to the incubation medium. Pargyline is a specific inhibitor of the enzyme monoamine oxidase and thus blocks serotonin catabolism. With serotonin breakdown blocked, the full amount of newly synthesized serotonin accumulates and the rate of total transmitter accumulation measures the rate of synthesis. Synthesis measured in this way provides results which are similar to those derived from other standard methods (Morot-Gaudry et al., 1974). Pargyline was added to slices in $5 \mathrm{ml}$ of incubation medium, and $2 \frac{1}{2}$ min later, some tissue was removed for analysis of initial tissue serotonin levels. The remaining slices were transferred to $5 \mathrm{ml}$ of fresh buffer

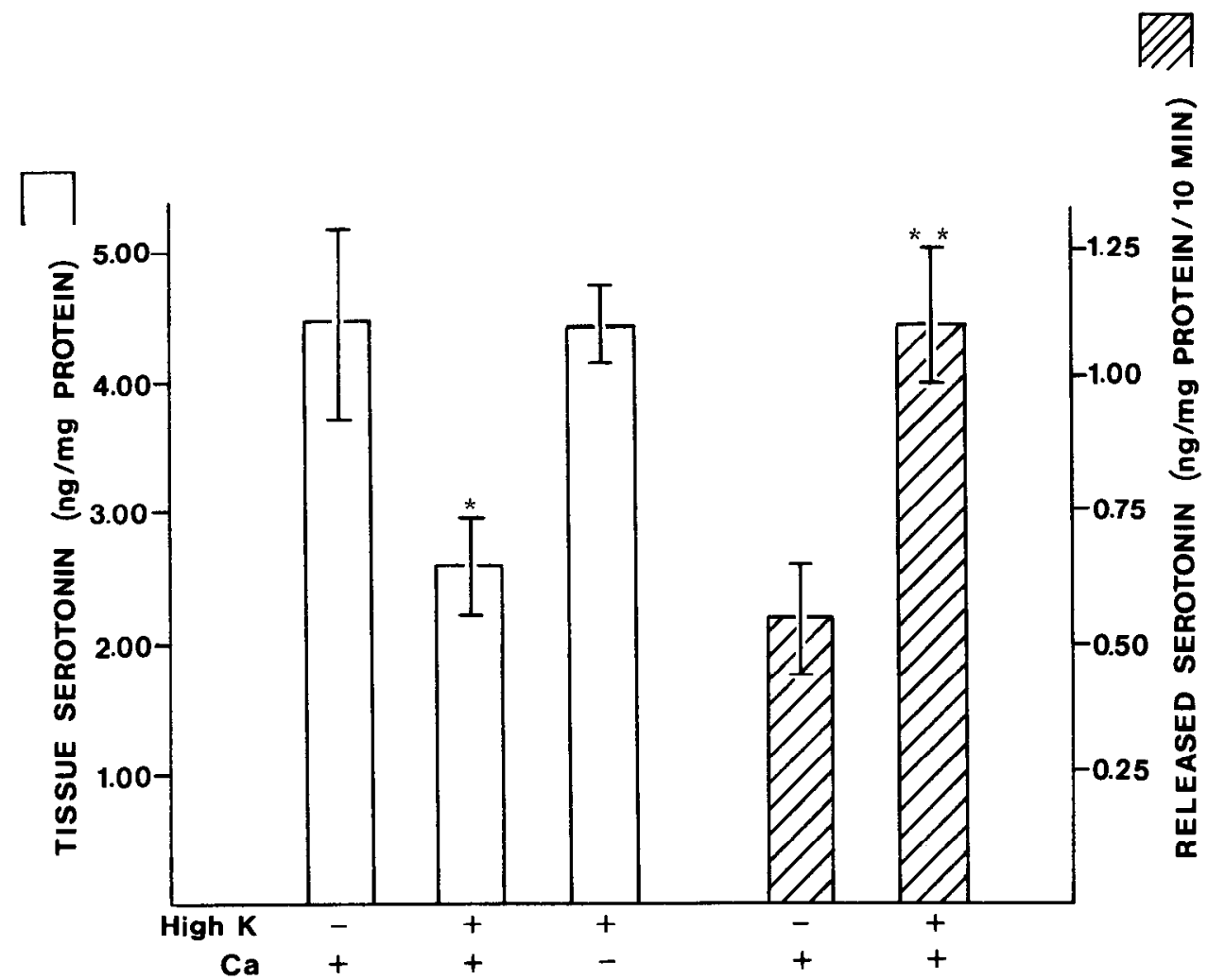

Figure 1. Depolarization-induced depletion of tissue serotonin and stimulation of serotonin release. Slices were incubated for $60 \mathrm{~min}$ in normal buffer and then incubated for an additional $10 \mathrm{~min}$ in normal, high $\mathrm{K}$, or high $\mathrm{K}$ without calcium (magnesium increased to $5.3 \mathrm{~mm}$ ) buffer. Before transfer to the calcium-free depolarizing buffer, slices were rinsed in a calcium-free buffer to remove adhering calcium. Tissue and released serotonin were analyzed as described under "Materials and Methods." Each value is the mean of 5 experimental samples \pm SEM. *, Difference from values in normal $\mathrm{K}$ or high $\mathrm{K}$ without calcium buffer significant at $p \leq 0.05$. **, Difference from values in slices incubated in normal $\mathrm{K}$ buffer significant at $p \leq 0.01$. (The Student's two-tailed unpaired $t$ test was used to determine the significance of differences in all experiments.) 
also containing pargyline. Ten minutes later, tissue was removed for serotonin analysis; in addition, the solution was analyzed for serotonin released during the preceding $10 \mathrm{~min}$. Synthesis during this 10 -min period was calculated as total serotonin (tissue + released) at the end of the period minus tissue serotonin at the beginning of the 10 -min period. The $2 \frac{1}{2} 2$-min pre-exposure to pargyline was necessary to ensure that the drug was acting throughout the period of synthesis measurement.

Materials. Synthetic Arg-vasopressin was obtained from three different sources: Sigma (grade VII), Bachem (Torrance, CA), or Peninsula Laboratories (San Carlos, CA). Vasopressin was dissolved in $0.1 \mathrm{~mm} \mathrm{HCl}$ immediately before use. Pargyline and imipramine were obtained from Sigma.

\section{Results}

Effect of high $K$ buffer on serotonin release and tissue levels. After the preincubation period, slices were transferred to buffer containing $60 \mathrm{mM} \mathrm{K} \mathrm{K}^{+}$iso-osmotically substituted for sodium (high $\mathrm{K}$ buffer). The effect of this depolarizing medium on tissue levels and the release of serotonin during the next $10 \mathrm{~min}$ is shown in Figure 1. Tissue serotonin declined by $35 \%$ and the decline was completely dependent upon the presence of calcium in the buffer. The 10-min incubation in high $\mathrm{K}$ buffer also increased the release of serotonin into the medium by about 2 -fold. The $\mathrm{K}$-activated decrease in tissue serotonin is almost 4 times as large as the $\mathrm{K}$-activated release of serotonin into the medium. This suggests that the decline in tissue serotonin is due to its catabolism as well as its release into the medium. Other workers have reported a similar decline in tissue serotonin during depolarization (Hamon et al., 1974).

Effect of vasopressin in high $K$ buffer. Tissue was exposed to $10^{-7} \mathrm{M}$ vasopressin for $10 \mathrm{~min}$ in normal buffer. Then it was transferred to high $\mathrm{K}$ buffer containing vasopressin for a further $10 \mathrm{~min}$. The effects of exposure to the peptide on tissue levels of serotonin and on released serotonin are shown in Figure 2. As shown by the two bars on the left, $10 \mathrm{~min}$ exposure to vasopressin did not affect serotonin levels of tissue incubated in normal buffer. However, as shown by the adjacent two bars, the peptide significantly blocked the depletion of serotonin during the subsequent 10-min depolarization. In addition, as shown by the two bars on the right, vasopressin increased the amount of serolonin released into the medium by about $60 \%$.

The effect of different concentrations of vasopressin on the depletion of tissue serotonin was tested. The results are shown in Figure 3. There is a dose-dependent effect of the peptide on serotonin depletion, but even the lowest dose tested, $10^{-9} \mathrm{M}$, partially blocked the depletion of the monoamine during exposure to high $\mathrm{K}$ buffer.

Increased release of serotonin from tissue coincident

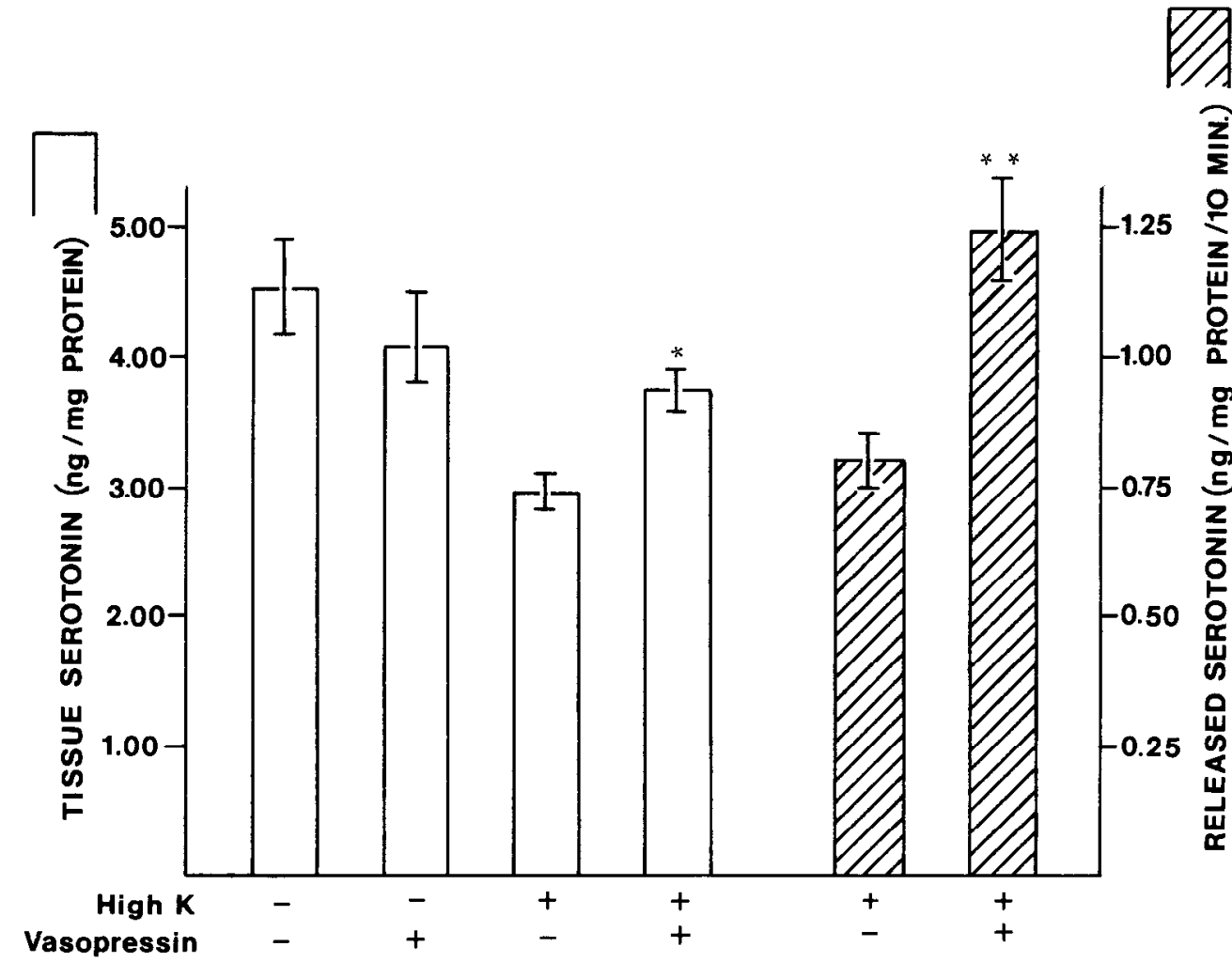

Figure 2. Effect of vasopressin on serotonin levels and release. Slices were incubated in normal buffer for 60 min. Vasopressin $\left(1 \times 10^{-7} \mathrm{M}\right)$ was added to experimental beakers and incubation continued for $10 \mathrm{~min}$ in normal buffer. At this point, some slices were frozen for analysis of tissue serotonin. These values are represented by the two left bars in the graph (each value, $n=6$ ). The other slices were transferred to high $\mathrm{K}$ buffer and incubated in the presence or absence of vasopressin. After 10 min, they were frozen and analyzed for tissue serotonin (middle two bars, $n=30$ for each value); buffers were analyzed for released serotonin ( two right hatched bars, $n=30$ for each value). *, Difference from endogenous value in high $\mathrm{K}$ buffer without vasopressin significant at $p \leq 0.01$. **, Difference from release value in high $\mathrm{K}$ buffer without vasopressin significant at $p \leq 0.001$. 
with less serotonin depletion in the tissue suggests that serotonin synthesis is more closely matched to its catabolism and release in the presence of vasopressin than in its absence. In order to test this inference, we measured the effect of vasopressin on the synthesis of serotonin during depolarization. The results are shown in Table II. It is apparent that vasopressin augments synthesis by about $60 \%$. Thus, in the presence of pargyline, vasopressin does not affect pre-depolarization levels of serotonin but does increase final tissue serotonin levels and also slightly increases the release of serotonin. In the absence of serotonin breakdown, this increase in total serotonin

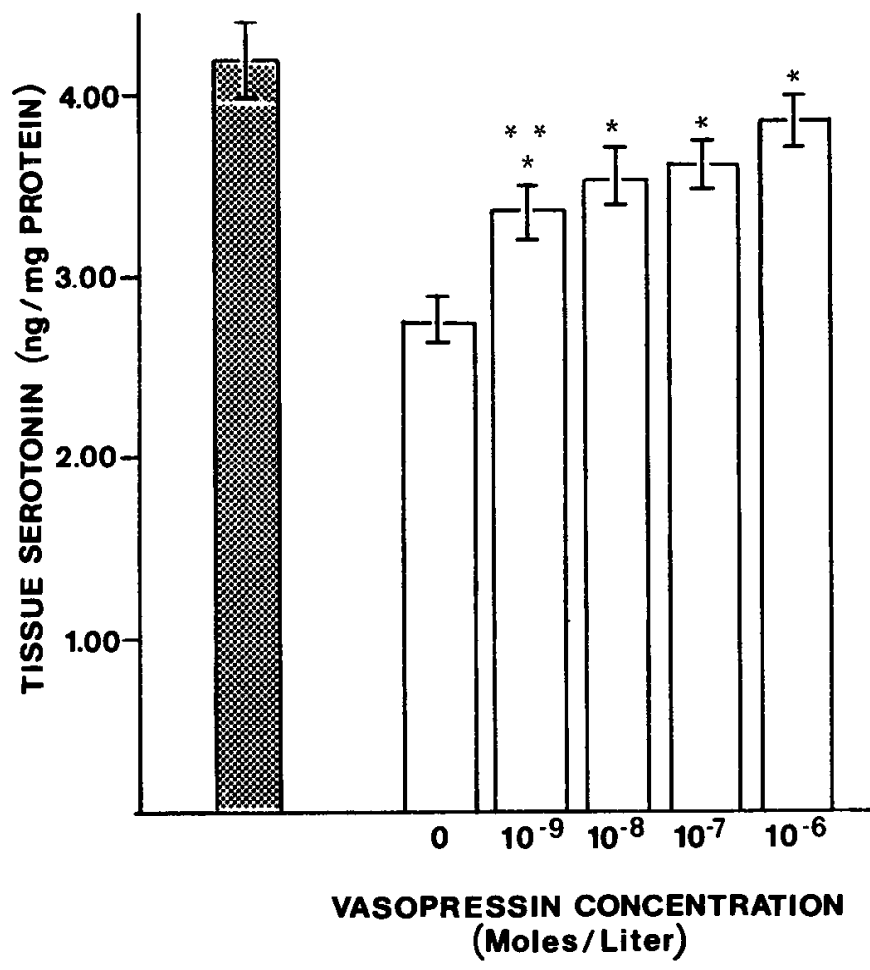

Figure 3. Tissue serotonin levels after incubation in high $\mathrm{K}$ buffer containing different concentrations of vasopressin. Slices were pre-exposed to vasopressin $\left(0\right.$ to $\left.1 \times 10^{-6} \mathrm{M}\right)$ for $10 \mathrm{~min}$ and then incubated for $10 \mathrm{~min}$ in high $\mathrm{K}$ buffer containing vasopressin $\left(0\right.$ to $1 \times 10^{-6} \mathrm{M}$ ). The stippled bar is the value for tissue serotonin before transfer to high $\mathrm{K}$ buffer. Each bar is the mean of 15 samples \pm SEM. *, Difference from value of no vasopressin control significant at $p<0.001 . * *$, Difference from $10^{-6} \mathrm{M}$ vasopressin value significant at $p<0.02$. is equivalent to the increase in synthesis caused by vasopressin.

Regional effects of vasopressin. Serotonin is concentrated in two distinct regions of the hippocampus, the stratum radiatum of $\mathrm{CAI}$ and the hilus of the dentate gyrus (Moore and Halaris, 1975). We measured the effect of vasopressin on the post-depolarization levels of serotonin in each of the regions separately. Slices were hemisected immediately after their preparation as shown in Figure 4. The cut was such that CA1 was in one of the hemisections and the dentate gyrus was in the other. The results are shown in Table III; it is apparent that the effect of the peptide is restricted to the hemi-slices containing the dentate gyrus.

\section{Discussion}

The measured tissue levels and synthesis rates of serotonin in the hippocampal slice are in good agreement with reported values of $3.8 \pm 0.5 \mathrm{ng} / \mathrm{mg}$ of protein for in vivo hippocampal levels (Saavedra, 1977) and 0.8 to 1.6 $\mathrm{ng} / \mathrm{mg}$ of protein/10 min for in vivo whole brain serotonin synthesis (Héry et al., 1972). Furthermore, the percentage increase in serotonin release during high $\mathrm{K}$ depolarization is very close to the percentage increase in serotonin release measured in vivo following strong stimulation of the raphe nucleus (Héry et al., 1979). Hence, the depolarized hippocampal slice may well be a valid model for studying the regulation of serotonin release. In addition, because there are no serotonin-containing somata in the hippocampus, the system provides a description of serotonin metabolism exclusively at nerve endings.

In the absence of vasopressin, high $\mathrm{K}$ depolarization leads to a release of serotonin and a coincident fall in tissue levels of the monoamine. A 10-min pre-exposure of the tissue to vasopressin augments that release by about $60 \%$ and, at the same time, almost completely prevents the drop in tissue levels of serotonin. Because serotonin release is actually augmented by vasopressin, these results show that the peptide must either increase serotonin synthesis or decrease serotonin breakdown (or both). There is no other way that tissue levels could be elevated in the presence of increased release of serotonin. Our studies show that serotonin synthesis is augmented; we have no information yet as to whether the breakdown of the monoamine is affected. While synthesis rates were not measured in normal $\mathrm{K}$ buffer, the effect of vasopressin on serotonin levels is confined to depolarized tissue.

Serotonin synthesis is activated during depolarization-

TABLE II

Effect of vasopressin on serotonin synthesis during high $K$ depolarization

Experimental (E) tissue was exposed to vasopressin for $10 \mathrm{~min}$ prior to depolarization. Two and one-half minutes before depolarization, $10^{-4}$ M pargyline was added to both bathing media. Pargyline was included throughout the rest of the experiment. Some tissue was analyzed just prior to exposure to high $\mathrm{K}$ buffer (initial tissue serotonin). The rest was exposed to high $\mathrm{K}$ buffer, and final tissue serotonin and released serotonin were measured in the usual way. All values represent the mean $\pm \mathrm{SEM} ; n=28$.

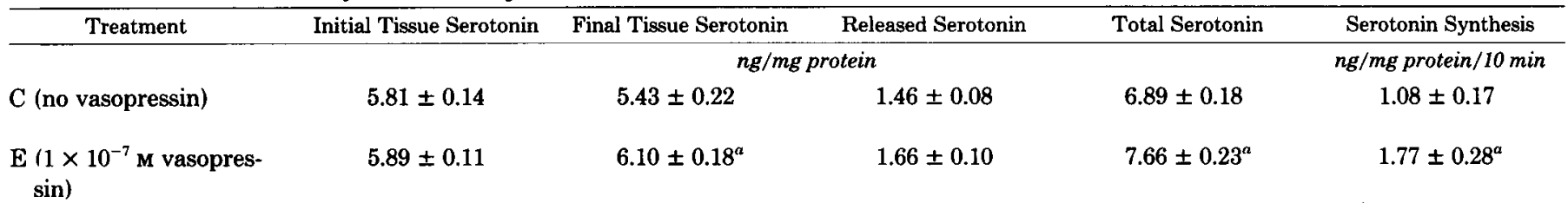

${ }^{a}$ Difference from control tissue value significant at $p<0.05$. 
TABLE III

Tissue serotonin levels in different hippocampal regions after $10 \mathrm{~min}$ depolarization

Slices were prepared and dissected as shown in Figure 4. The sections were incubated in the normal way and analyzed following $10 \mathrm{~min}$ exposure to high $\mathrm{K}$ buffer. Each value is the mean of 13 experimental samples \pm SEM.

\begin{tabular}{lcc}
\hline Hippocampal Region & $10^{-7} \mathrm{M}$ Vasopressin & Serotonin \\
\hline \multirow{2}{*}{ CA1 } & - & $n g / m g$ protein \\
& + & $3.30 \pm 0.11$ \\
Dentate gyrus & - & $3.42 \pm 0.17$ \\
& + & $3.41 \pm 0.17$ \\
& & $1.37 \pm 0.18^{a}$ \\
\hline
\end{tabular}

"Difference from untreated dentate gyrus section value significant at $p<0.005$.

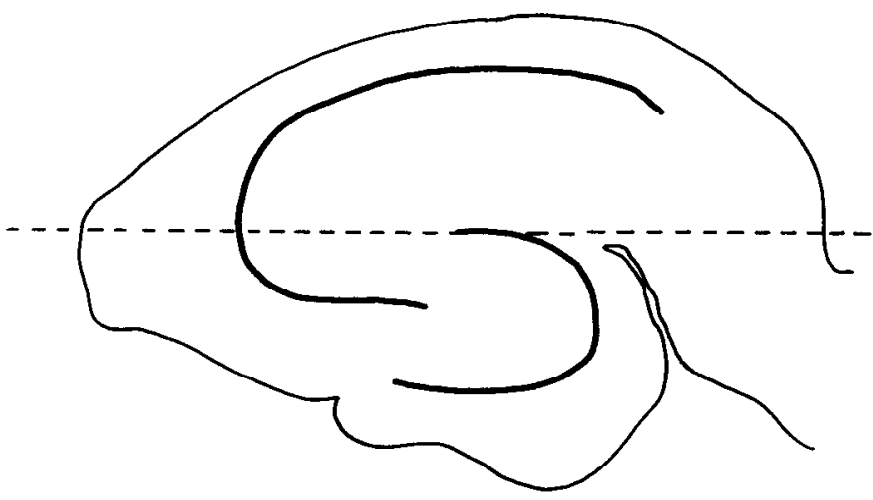

Figure 4. Dissection of hippocampal slices. Hippocampal slices were dissected out and cut as shown by the dotted line. The bottom section is the dentate gyrus-containing tissue. The top section is the CAl-containing tissue.

induced release of serotonin (Hamon et al., 1979); this activation very likely results from an activation of tryptophan hydroxylase by calcium entering the nerve terminals during the depolarization (Boadle-Biber, 1979). Vasopressin apparently increases cytosolic calcium in liver (Tolbert et al., 1980) and it is reasonable to postulate that it may be acting similarly at the serotonergic nerve endings; in this way, by increasing cytosolic calcium, it might well activate both exocytosis and synthesis of serotonin. On the other hand, vasopressin may be acting directly to increase the rate of serotonin synthesis during depolarization with the increase in release resulting indirectly from an augmented supply of serotonin. The possibility of such a mechanism is suggested by the observed effect of pargyline. This inhibition of monoamine oxidase causes a rapid increase in tissue levels of serotonin in normal $\mathrm{K}$ buffer and largely prevents the depletion of tissue serotonin which normally occurs during tissue depolarization. This maintenance of tissue levels is associated with an augmented depolarizationinduced release of serotonin. Similar results were observed by Elks et al. (1979). Inhibitors of monoamine oxidase, such as pargyline, are not thought to affect exocytosis directly (Grahame-Smith, 1971; Baker et al., 1980) so that the results suggest that serotonin release can be activated by augmented tissue levels during depolarization.
This mechanism also can account for the relatively small effect of vasopressin on serotonin release when pargyline-treated tissue is depolarized. Thus, tissue levels and serotonin release are already augmented by pargyline. It is quite possible that the further increment due to vasopressin will have a small effect on serotonin release if, for example, a releasable pool of serotonin is largely saturated by the action of pargyline. Thus, our data are consistent with the conclusion that vasopressin, like pargyline, augments depolarization-induced release of serotonin by increasing the ratio of serotonin synthesis to serotonin breakdown and, hence, increasing tissue serotonin during depolarization.

The fact that pargyline prevents depletion of serotonin during tissue depolarization in spite of the large value of serotonin release suggests that it is serotonin breakdown which accounts for the majority of the net loss of tissue serotonin during depolarization. This is consistent with the data in Figure 2 which shows that, during depolarization in the presence of imipramine to block re-uptake, the depletion of tissue serotonin is far greater than the release of the monoamine.

While the mechanism of its action is unresolved, vasopressin clearly can activate the release of serotonin from depolarized nerve endings in the hippocampus. In vivo studies have demonstrated that the peptide activates norepinephrine and serotonin turnover in brain (Versteeg et al., 1978; Kovács et al., 1980). The present work shows that the peptide actually augments the release of monoamine. Furthermore, it localizes an effect of vasopressin to nerve endings. Such presynaptic modulatory actions have been reported for other peptides. Thus, $\alpha$-melanocyte-stimulating hormone, adrenocorticotrophic hormone, and somatostatin all reportedly act on nerve terminals in the hippocampus to increase the turnover rate of acetylcholine (Wood et al., 1979). Similarly, $\left[{ }^{3} \mathrm{H}\right]$ serotonin release from rat hippocampal and cortical slices is increased by in vitro treatment with somatostatin (Tanaka and Tsujmoto, 1981).

The localization of vasopressin action to only one of the hippocaripal regions containing serotonin suggests a specific function for the interaction that we have described. Transmission through the dentate gyrus is facilitated by local release of serotonin (Winson, 1980). Vasopressin thus might augment transmission through this pathway. Small alterations in serotonin metabolism of the magnitude that we report here have been associated with profound changes in behavior of experimental animals (McBride et al., 1976; Trulson and Jacobs, 1979).

\section{References}

Baker, G. B., L. E. Hiob, and W. G. Dewhurst (1980) Effects of monoamine oxidase inhibitors on release of dopamine and 5hydroxytryptamine from rat striatum in vitro. Cell. Mol. Biol. 26: 182-186.

Boadle-Biber, M. (1979) Activation of tryptophan hydroxylase from slices of rat brain stem incubated with agents which promote calcium uptake or intraneuronal release. Biochem. Pharmacol. 28: 2129-2138.

Bohus, B., G. L. Kovács, and D. DeWied (1978) Oxytocin, vasopressin and memory: Opposite effects on consolidation and retrieval processes. Brain Res. 157: 414-417.

Boireau, A., J. P. Ternaux, S. Bourgoin, F. Héry, J. Glowinski, 
and M. Hamon (1976) The determination of picogram levels of 5-HT in biological fluids. J. Neurochem. 26: 201-204.

Buijs, R. M. (1978) Intra- and extrahypothalamic vasopressin and oxytocin pathways in the rat: Pathways to the limbic system, medulla oblongata and spinal cord. Cell Tissue Res. 192: 423-435.

Elks, M. L., W. W. Youngblood, and J. S. Kizer (1979) Serotonin synthesis and release in brain slices: Independence of tryptophan. Brain Res. 172: 471-486.

Grahame-Smith, D. G. (1971) Studies in vivo on the relationship between brain tryptophan, brain 5 -HT synthesis and hyperactivity in rats treated with a monoamine oxidase inhibitor and L-tryptophan. J. Neurochem. 18: 1053-1066.

Hamon, M., S. Bourgoin, J. Jagger, and J. Glowinski (1974) Effects of LSD on synthesis and release of $5-\mathrm{HT}$ in rat brain slices. Brain Res. 69: 265-280.

Hamon, M., S. Bourgoin, F. Artaud, and J. Glowinski (1979) The role of intraneuronal 5-H'T and of tryptophan hydroxylase activation in the control of 5-HT synthesis in rat brain slices incubated in $\mathrm{K}^{+}$-enriched medium. J. Neurochem. 33: 1031-1042.

Héry, F., E. Rouer, and J. Glowinski (1972) Daily variation of serotonin metabolism in the rat brain. Brain Res. 43: 445465.

Héry, F., G. Simonnet, S. Bourgoin, P. Soubrié, F. Artaud, M. Hamon, and J. Glowinski (1979) Effect of nerve activity on the in vivo release of $\left[{ }^{3} \mathrm{H}\right]$ serotonin continuously formed from $\mathrm{L}-\left[{ }^{3} \mathrm{H}\right]$ tryptophan in the caudate nucleus of the cat. Brain Res. 169: 317-334.

Kovács, G. L., B. Bohus, D. H. G. Versteeg, E. R. DeKluet, and D. DeWied (1979) Effect of oxytocin and vasopressin on memory consolidation: Sites of action and catecholaminergic correlates after local microinjection into limbic-midbrain structures. Brain Res. 175: 303-314.

Kovács, G. L., G. Szabo, L. Szontágh, L. Medve, G. Telegdy, and F. A. László (1980) Hereditary diabetes insipidus in rats: Altered cerebral and catecholamine metabolism. Neuroendocrinology 31: 189-193.

Lowry, O. H., N. J. Rosebrough, A. L. Farr, and R. J. Randall (1951) Protein measurement with the Folin phenol reagent. J. Biol. Chem. 193: 265-275.

McBride, W. J., T. P. Hyde, J. D. Smith, J. D. Lane, and M. H. Aprison (1976) Effects of tryptophan on serotonin in nerve endings. J. Neurochem. 26: 175-178.

Moore, R. Y., and A. E. Halaris (1975) Hippocampal innervation by serotonin neurons of the midbrain raphe in the rat. $\mathrm{J}$. Comp. Neurol. 164: 171-184.
Morot-Gaudry, Y., M. Hamon, S. Bourgoin, J. P. Ley, and J. Glowinski (1974) Estimation of the rate of 5-HT synthesis in the mouse brain by various methods. Naunyn Schmiedebergs Arch. Pharmacol. 282: 223-238.

Ramaekers, F., H. Rigter, and B. E. Leonard (1977) Parallel changes in behavior and hippocampal serotonin metabolism in rats following treatments with desglycinamide lysine vasopressin. Brain Res. 120: 485-492.

Saavedra, J. M. (1977) Distribution of serotonin and synthesizing enzymes in discrete areas of the brain. Fed. Proc. 36: 2134-2141.

Shaskan, E. G., and S. H. Snyder (1970) Kinetics of serotonin accumulation into slices from rat brain: Relationship to catecholamine uptake. J. Pharmacol. Exp. Ther. 175: 404-418.

Skrede, K. K., and R. H. Westgaard (1971) The transverse hippocampal slice. A well-defined cortical structure maintained in vitro. Brain Res. 35: 589-593.

Sofroniew, M. W. (1980) Projections from vasopressin, oxytocin, and neurophysin neurons to neural targets in the rat and human. J. Histochem. Cytochem. 28: 475-478.

Tanaka, S., and A. Tsujmoto (1981) Somatostatin facilitates the serotonin release from rat cerebral cortex, hippocampus and hypothalamus slices. Brain Res. 208: 219-222.

Tolbert, M. E. M., A. C. White, K. Aspry, J. Cutts, and J. N. Fain (1980) Stimulation by vasopressin and $\alpha$-catecholamines of phosphatidylinositol formation in isolated rat liver parenchymal cells. J. Biol. Chem. 255: 1939-1944.

Trulson, M. E., and B. L. Jacobs (1979) Long-term amphetamine treatment decreases brain serotonin metabolism: Implications for theories of schizophrenia. Science 205: 12951297.

Versteeg, D. H. G., M. Tanaka, and E. R. deKloet (1978) Catecholamine concentration and turnover in discrete regions of the brain of the homozygous Brattleboro rat deficient in vasopressin. Endocrinology 103: 1654-1661.

Weingartner, H., P. Gold, J. C. Ballenger, S. A. Smallberg, R. Summers, D. R. Rubinow, R. M. Post, and F. K. Goodwin (1981) Effects of vasopressin on human memory functions. Science 211: 601-603.

Winson, J. (1980) Influence of raphe nuclei on neuronal transmission from perforant pathway through dentate gyrus. $\mathrm{J}$. Neurophysiol. 44: 937-950.

Wood, P. L., D. L. Cheney, and E. Costa (1979) Modulation of the turnover rate of hippocampal acetylcholine by neuropeptides: Possible site of action of $\alpha$-melanocyte-stimulating hormone, adrenocorticotrophic hormone and somatostatin. J. Pharmacol. Exp. Ther. 209: 97-103. 